\title{
SOME COMPRESSIVE TESTS OF HOLLOW-TILE WALLS.
}

\author{
By Herbert L. Whittemore and Bernard D. Hathcock:
}

ABSTRACT.

To supplement the tests of individual hollow building tile made by the Bureau of Standards at its Pittsburgh laboratory, tests of walls built from similar tile were made in the ro, 000,000 -pound hydraulic testing machine.

These walls were either 6,8 , or I 2 inches thick and 4 feet long by 12 feet high.

The tile were tested individually, and their strength was much greater than those usually used in building construction. Their design was such that all the net area was in bearing when carefully set on end in the wall. The walls were carefully laid by an experienced mason and undoubtedly had a greater strength than those in buildings.

Of the 32 walls about half were built with the cells of the tile vertical and half with the cells horizontal. A few walls of each construction were tested under a load having an eccentricity of 2 inches.

Considerable differences in the strength of the tile did not have an appreciable effect on the strength of the walls. No relation was found between the ultimate strength and the load at first crack.

The stress at failure computed on the net sectional area was remarkably constant for lot A tile, on end, being independent of the size of the tile.

Walls having the cells of the tile vertical had, on the average, more than twice the strength of those having the cells horizontal.

Walls loaded with an eccentricity of 2 inches, over one-half the width of the wall, had about one-half the strength of similar walls axially loaded. Apparently this ratio is independent of the thickness of the wall.

No relation could be found between the modulus of elasticity of the walls and that of the tile.

\section{CONTENTS.}

Page.

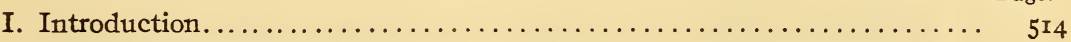

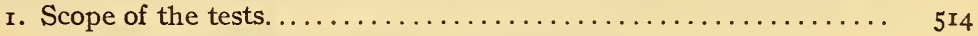

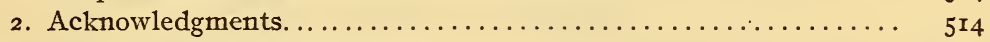

II. Description of the material and walls $\ldots \ldots \ldots \ldots \ldots \ldots \ldots \ldots \ldots \ldots \ldots \ldots \ldots \ldots \ldots \ldots$

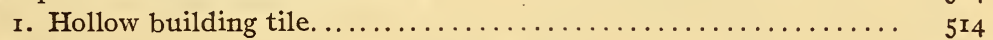

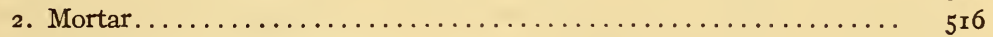

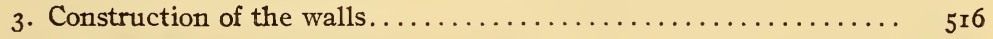

III. Details of the tests. . . . . . . . . .

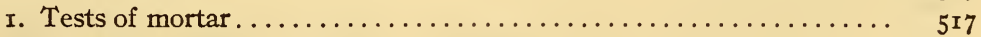

2. Tests of individual tile. ...................... 5 I 7

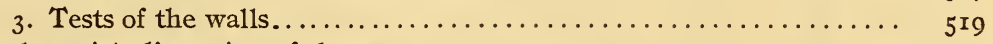

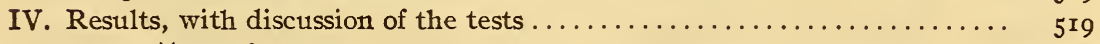

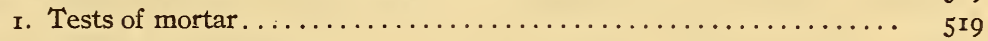

2. Tests of individual tile........................ 5 I9

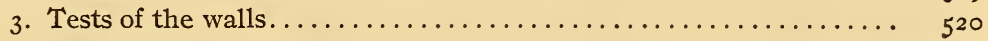

V. General summary .................................. 523 


\section{INTRODUCTION.}

\section{SCOPE OF THE TESTS.}

The Bureau of Standards has for a number of years conducted tests to determine the strength and other physical properties of hollow building tile. Some of the test results have already been published ${ }^{1}$ and are concerned with the compressive strength and absorption of the individual tile. Other tests, those reported here, have been conducted to determine the compressive strength of walls built of this material.

This investigation was planned by J. H. Griffith, of the Bureau of Standards, in cooperation with the officials of the National Fire Proofing Co. A. V. Bleininger, of the ceramics division of this bureau, acted in an advisory capacity. Some time after the work had been started committee C-IO, on hollow building tile, of the American Society for Testing Materials, was instructed to conduct a similar investigation. To avoid needless duplication it was thought desirable to cooperate with that commitiee in so far as possible.

At a conference between the interested parties it was decided that the thickness of the walls to be tested should be 6,8 , and 12 inches, the length of each wall 4 feet, and the height 12 courses of 12 -inch tile. The other features were to conform to the original program of the bureau and are given in more detail later.

\section{ACKNOWLEDGMENTS.}

Acknowledgments are due the National Fire Proofing Co., particularly R. W. Allison and P. H. Bevier, for donating all the tiles used for these walls.

\section{DESCRIPTION OF THE MATERIAL AND WALLS.}

\section{HOLLOW BUILDING TILE.}

The tile made from fire clay used in walls I to 24 were designated as lot $\mathrm{A}$ and came from a factory in Ohio; those made from plastic clay in walls 25 to 32 , and designated as lot B, came from New Jersey.

The instructions for selecting the samples were that "the tile are to be of a grade which conforms to good commercial practice, without reference to the degree of burning" in the kilns. The samples were chosen by the manufacturer, using the methods usual for building construction.

\footnotetext{
${ }^{1}$ B. S. Tech. Paper No. r2o, Tests of Hollow Building Tile, by Hathcock and Skillman.
} 
All tile were I 2 inches long, I 2 inches wide, and either 6, 8, or 12 inches thick. The 6 and 8 inch tile had four large longitudinal cells or openings, but the $\mathrm{r} 2$-inch tile had six of these spaces. Typical end views of each size are shown in Figure $\mathrm{I}$. The outside surfaces had grooves to provide an efficient bond with the mortar. Double webs across the tile, moreover, gave

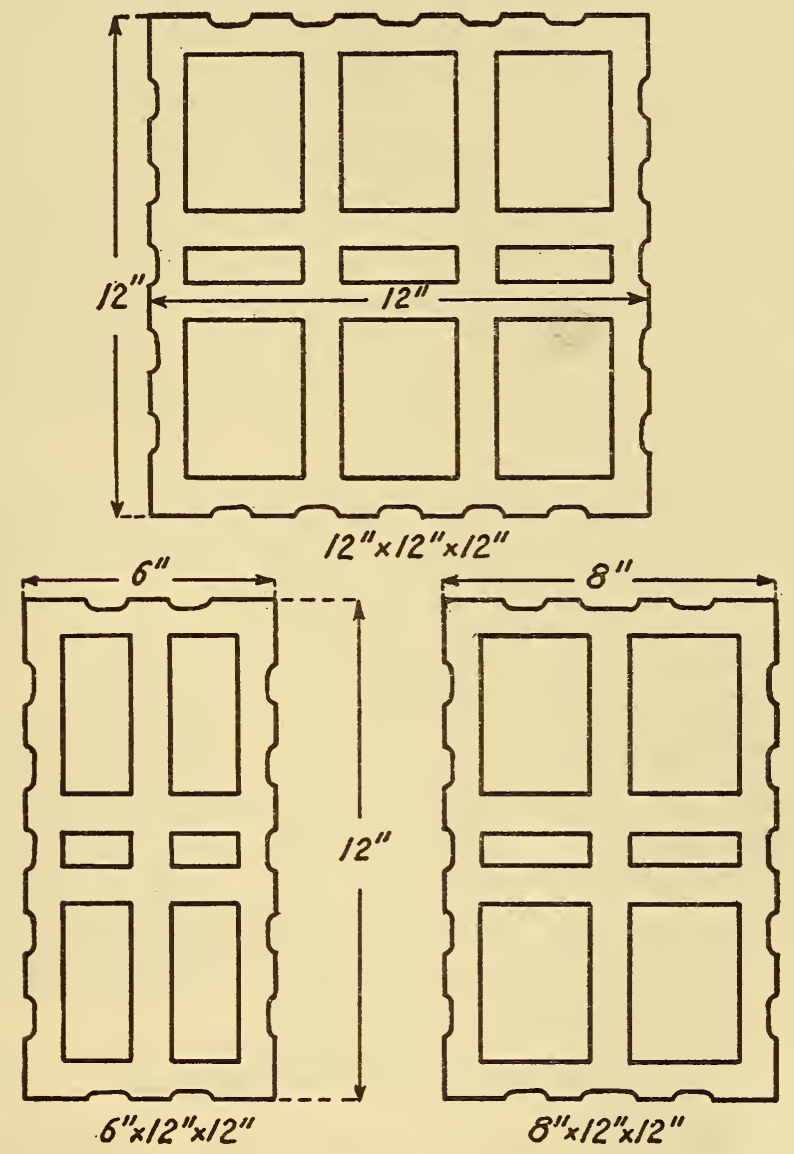

FIG. I.-End view of tile.

bearing surfaces for the edges of adjoining tile when the joints are broken in the usual manner.

The high strength of these walls and of the tile used in building them was due not so much to the selection of strong tile as to the characteristics of the clay from which the tile were made.

The strength of these tile was greater than the average obtained on many samples of the tile tested at the Bureau of Standards. The value of the results of this investigation, 
therefore, will lie not in the strength of the walls, but in the relation of the strength to the manner of loading and to the strength of the individual tile.

\section{MORTAR.}

The mortar was given careful consideration. Some experts believed that the mortar for tile walls should consist only of cement and sand without the addition of lime. If the tile are set with the cells vertical and this mortar is used, much of it falls off the narrow edges of the tile and makes considerable "pointing" of the joints necessary later. Moreover, considerable care and labor are required to spread cement mortar which lacks the plasticity of lime mortar. The joints for these reasons are not filled as completely with cement mortar as with more plastic mortars. Tests of brick piers ${ }^{2}$ in this and other laboratories have shown the great strength of those in which lime-cement mortars were used.

Having considered the properties of lime-cement mortars, particularly the values obtained by W. E. Emley, ${ }^{3}$ the following composition for the mortar was adopted:

I cubic foot Portland cement

$1 / 4$ cubic foot hydrated lime

3 cubic feet sand (oven dry)

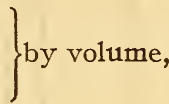

equals approximately:

94 pounds Portland cement

Io pounds hydrated lime

300 pounds sand (oven dry) \}by weight.

The cement and the lime were of good quality. In mixing the mortar sufficient water was added to give the plasticity desired by the mason.

\section{CONSTRUCTION OF THE WALIS.}

All the walls were about 4 feet long and 12 feet high. They were laid with great care by an experienced mason and were of much better workmanship than is obtained in practice. The results obtained from these walls should not be used in design unless the proper allowances are made, but if this is done it is believed that many of the conclusions are of value in construction work.

2 B. S. Tech. Paper No. rir, Compressive Strength of Large Brick Piers, by Bragg.

${ }^{3}$ Properties of cement-lime-sand mortars, W. E.. Emley, Proc., Amer. Soc, for Testing Materials, p. 26r; I9Iy. 
Bureau of Standards Technologic Papers, Vol.17

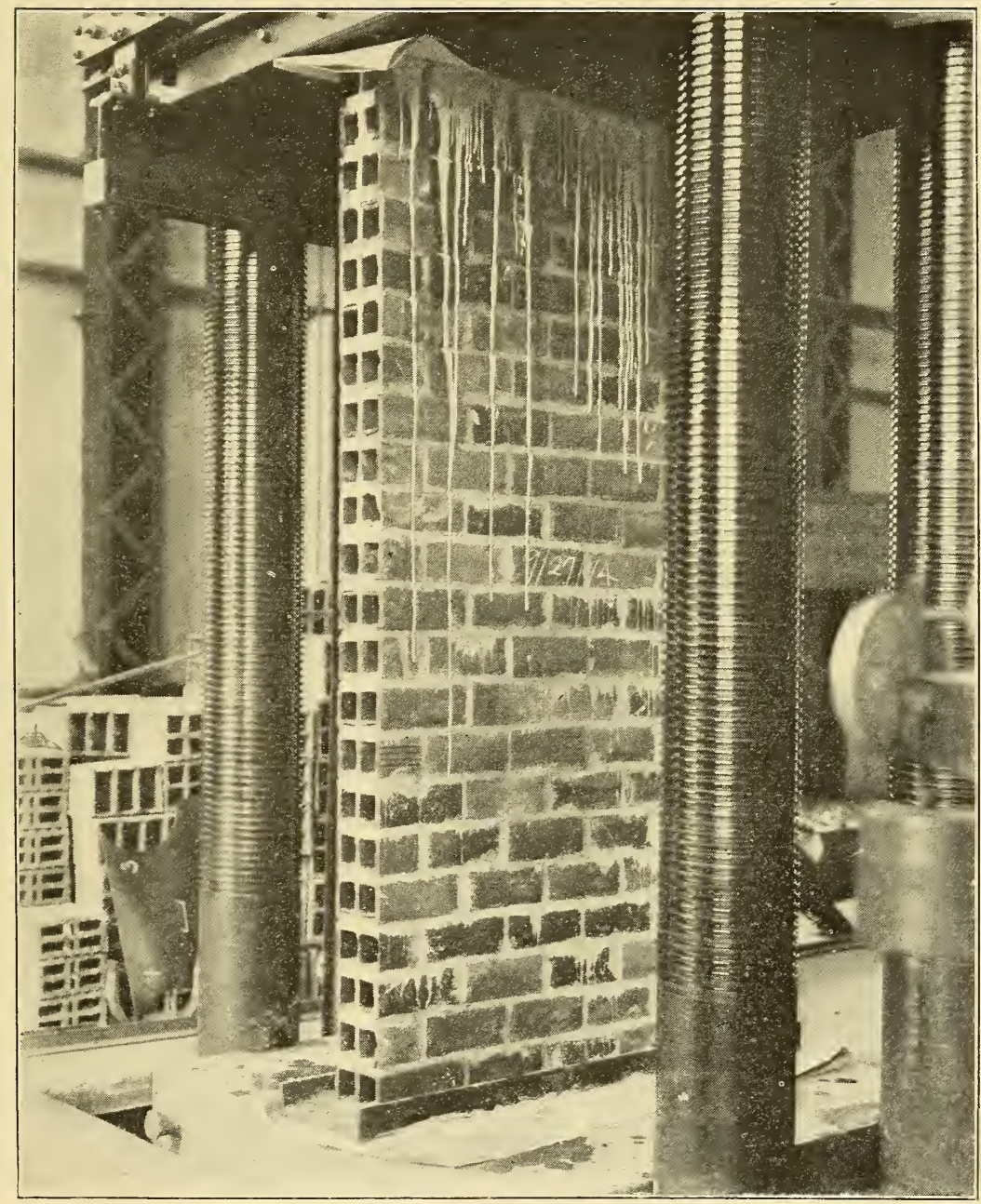

FIG. 2.-Tile wall in testing machine.

The wall shown here was not tested for this investigation, but the photograph shows the method of testing. 

The walls were built in the laboratory on metal base plates. One surface was machine finished. The plate was carefully leveled on the floor before starting the wall to make the bottom surface of the wall perpendicular to the vertical axis. The tile were wet thoroughly, using a hose, before laying. All joints were filled with mortar. The mason tried to make the horizontal joints with an average thickness of three-eighths inch. Due to irregularities in the tile, it was impossible to obtain a uniform thickness of the vertical joints.

The base plates were provided with yokes for lifting the walls into position in the 10,000,000-pound hydraulic testing machine by means of a crane. The machined surface of the plate rested on the lower head of the testing machine. To make the axis of the wall lie in the axis of the machine, the lower head was tilted in its spherical bearing. A layer of freshly mixed plaster of Paris was spread over the top of the wall and the excess plaster squeezed out (fig. 2) by lowering the upper head. After capping, from I2 to 20 hours elapsed before testing.

It was planned to test the walls one month after building, but for four of the walls (Nos. I9 to 22) the tests were unavoidably delayed, so that they were from 65 to 277 days old. These walls were all in Series III, which was loadéd eccentrically.

\section{DETAILS OF THE TESTS.}

\section{TESTS OF MORTAR.}

Several tests were made on the mortar to determine its physical properties. For these mortar tests the water was II.2 per cent, by weight, of the dry material and the yield I cubic foot of mortar for 127.5 pounds of the dry ingredients. The tensile and the compressive strength was measured for several ages when stored in air and when stored in water.

\section{TESTS OF INDIVIDUAL TILE.}

Six tile of each size of the A tile and the same number of the $B$ tile were tested in compression after being capped with plaster of Paris. Three from each lot were tested with the cells parallel to the action line of the load and three with the cells perpendicular to the load. The small number of samples selected to determine the physical properties of the individual tile should be taken into consideration when comparing the values of the tile and the walls, as from 5 to ro specimens have been found necessary to obtain reliable average values. 
The cross sections of five tile from each lot were obtained and the average used in computing the net sectional area of the walls. After the compressive tests, samples, approximately square, free from cracks, and having an area of from $\mathrm{I} 2$ to 20 square inches, were selected from each of the tile for the absorption tests. The samples were dried at about $\mathrm{I} 20^{\circ} \mathrm{C}$. $\left(248^{\circ} \mathrm{F}\right.$.) until the weight became constant, then boiled in distilled water for five hours. The results are given in Table $\mathrm{I}$.

TABLE 1.-Tests of Individual Tile.

\begin{tabular}{|c|c|c|c|c|c|c|c|c|c|}
\hline \multirow{2}{*}{$\begin{array}{l}\text { Tile } \\
\text { from } \\
\text { lot- }\end{array}$} & \multirow{2}{*}{$\begin{array}{l}\text { Size of tile } \\
\text { (inches). }\end{array}$} & \multirow{2}{*}{$\begin{array}{l}\text { Direction } \\
\text { of cells. }\end{array}$} & \multirow{2}{*}{ Color. } & \multirow{2}{*}{$\begin{array}{c}\text { Netsec- } \\
\text { tional } \\
\text { area. }\end{array}$} & \multirow{2}{*}{$\begin{array}{l}\text { Absorp- } \\
\text { tion. }\end{array}$} & \multicolumn{2}{|c|}{ Ultimate strength. } & \multirow{2}{*}{$\begin{array}{c}\text { Strength } \\
\text { at first } \\
\text { crack, } \\
\text { net area. }\end{array}$} & \multirow{2}{*}{$\begin{array}{l}\text { Modulus } \\
\text { of elas- } \\
\text { ticity, } \\
\text { net area. }\end{array}$} \\
\hline & & & & & & $\begin{array}{l}\text { Gross } \\
\text { area. }\end{array}$ & $\begin{array}{l}\text { Net } \\
\text { area. }\end{array}$ & & \\
\hline \multirow[t]{2}{*}{$\begin{array}{l}\text { A } \\
\text { A.......... } \\
\text { A........ }\end{array}$} & $\begin{array}{c}12 \text { by } 12 \text { by } 12 . . . \\
\ldots \ldots \text { do } \\
\ldots \ldots . . . . . . . . .\end{array}$ & \multirow[t]{2}{*}{$\begin{array}{l}\text { Vertical.... } \\
\text { ….do........ } \\
\text {....do..... }\end{array}$} & \multirow[t]{2}{*}{$\begin{array}{l}\text { Light.... } \\
\text { Medium }\end{array}$} & $\begin{array}{r}\text { Sq. in. } \\
58.1 \\
63.8 \\
56.9\end{array}$ & $\begin{array}{r}\text { Per ct. } \\
7.2 \\
8.8 \\
6.3\end{array}$ & $\begin{array}{c}\text { Lbs./in. }{ }^{2} \\
2,960 \\
2,635 \\
2,970\end{array}$ & $\begin{array}{r}\text { Lbs./in. }{ }^{2} \\
7,340 \\
5,940 \\
7,520\end{array}$ & \begin{tabular}{|c|} 
Lbs./in. \\
5, 000 \\
5,000 \\
5,500
\end{tabular} & $\begin{array}{l}\text { Lbs./in. }{ }^{2} \\
3,400,000 \\
3,570,000 \\
3,850,000\end{array}$ \\
\hline & Average.. & & & 59.6 & 7.4 & 2,855 & 6,930 & 5,170 & $3,610,000$ \\
\hline \multirow[t]{2}{*}{$\begin{array}{l}\text { A....... } \\
\text { A........ } \\
\text { A....... }\end{array}$} & 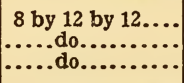 & \multirow[t]{2}{*}{$\begin{array}{l}\text { Vertical..... } \\
\ldots \ldots \text { do....................... }\end{array}$} & \multirow[t]{2}{*}{$\begin{array}{c}\text { Medium } \\
\ldots . \text { do....... } \\
\ldots . \text { do..... }\end{array}$} & $\begin{array}{l}42.7 \\
43.9 \\
46.5\end{array}$ & $\begin{array}{l}6.3 \\
9.0 \\
9.9\end{array}$ & $\begin{array}{l}2,270 \\
2,260 \\
2,420\end{array}$ & & $\begin{array}{l}3,000 \\
4,940 \\
4,980\end{array}$ & $\begin{array}{l}3,450,000 \\
3,180,000 \\
2,700,000\end{array}$ \\
\hline & Average.. & & & 44.4 & 8.4 & 2,320 & 5,010 & 4,310 & $3,110,000$ \\
\hline \multirow[t]{2}{*}{$\begin{array}{l}\text { A....... } \\
\text { A........ } \\
\text { A....... }\end{array}$} & 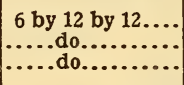 & \multirow[t]{2}{*}{\begin{tabular}{|} 
Vertical ..... \\
$\ldots \ldots$ do $\ldots . . .$. \\
$\ldots .$. do $0 . . .$.
\end{tabular}} & \multirow[t]{2}{*}{$\begin{array}{l}\text { Dark.... } \\
\text {.do do..... } \\
\text { Medium }\end{array}$} & $\begin{array}{l}33.8 \\
34.1 \\
33.7\end{array}$ & $\begin{array}{l}4.9 \\
4.6 \\
4.4\end{array}$ & $\begin{array}{l}4,660 \\
3,880 \\
3,510\end{array}$ & & $\begin{array}{l}7,000 \\
5,000 \\
4,000\end{array}$ & $\begin{array}{l}5,130,000 \\
4,580,000 \\
2,700,000\end{array}$ \\
\hline & Average.. & & & 33.9 & 4.6 & 4,020 & 8,520 & 5,330 & $4,140,000$ \\
\hline \multirow[t]{2}{*}{$\begin{array}{l}\text { A } \\
\text { A } \ldots \ldots . . . \\
\text { A......... }\end{array}$} & $\begin{array}{c}12 \text { by } 12 \text { by } 12 \ldots \\
\cdots \ldots . \text { do } \ldots \ldots \ldots \ldots\end{array}$ & \multirow[t]{2}{*}{$\begin{array}{c}\text { Horizontal.. } \\
\ldots \ldots . \text { do....... } \\
\ldots \ldots \text {..do...... }\end{array}$} & \multirow[t]{2}{*}{$\begin{array}{c}\text { Light.... } \\
\text { ido d.... } \\
\text { Medium }\end{array}$} & $\begin{array}{l}32.4 \\
31.2 \\
32.4\end{array}$ & $\begin{array}{l}7.8 \\
5.3 \\
5.4\end{array}$ & $\begin{array}{l}760 \\
960 \\
800\end{array}$ & & $\begin{array}{l}2,410 \\
3,170 \\
2,130\end{array}$ & $\begin{array}{l}\cdots \\
\cdots \\
\cdots\end{array}$ \\
\hline & Average.. & & & 32.0 & 6.2 & 840 & 3,780 & 2,570 & \\
\hline \multirow[t]{2}{*}{$\begin{array}{l}\text { A } \ldots \ldots . . . \\
\text { A } \ldots \ldots \ldots . \\
\text { A........ }\end{array}$} & 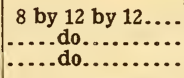 & \multirow[t]{2}{*}{$\begin{array}{c}\text { Horizontal.. } \\
\ldots \ldots . \text { do } . . . . . . \\
\ldots \text {...do...... }\end{array}$} & \multirow[t]{2}{*}{$\begin{array}{l}\text { Dark.... } \\
\text { Medium } \\
\text { Dark.... }\end{array}$} & $\begin{array}{l}21.6 \\
21.6 \\
21.6\end{array}$ & $\begin{array}{l}7.3 \\
5.4 \\
6.0\end{array}$ & $\begin{array}{l}1,175 \\
1,230 \\
1,310\end{array}$ & & $\begin{array}{l}4,630 \\
5,370 \\
3,610\end{array}$ & \\
\hline & Average.. & & & 21.6 & 6.2 & 1,240 & 5,460 & 4,540 & \\
\hline \multirow[t]{2}{*}{$\begin{array}{l}\text { A } \ldots \ldots . . \\
\text { A } \ldots . . . . . \\
\text { A....... }\end{array}$} & $\begin{array}{c}6 \text { by } 12 \text { by } 12 \ldots \\
\cdots \\
\cdots\end{array}$ & \multirow[t]{2}{*}{$\begin{array}{c}\text { Horizontal. } \\
\cdots . . \text { do } \\
\end{array}$} & \multirow[t]{2}{*}{$\begin{array}{l}\text { Medium } \\
\text {...do....... } \\
\text {...do..... }\end{array}$} & $\begin{array}{l}18.0 \\
21.6 \\
21.6\end{array}$ & $\begin{array}{l}4.8 \\
5.4 \\
7.5\end{array}$ & $\begin{array}{l}1,685 \\
1,710 \\
1,600\end{array}$ & & $\begin{array}{l}3,200 \\
2,040 \\
2,220\end{array}$ & \\
\hline & Average. & & & 20.4 & 5.9 & 1,665 & 5,930 & 2,490 & \\
\hline \multirow[t]{2}{*}{$\begin{array}{l}\text { B...... } \\
\text { B....... } \\
\text { B....... }\end{array}$} & 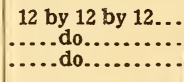 & \multirow[t]{2}{*}{$\begin{array}{l}\text { Vertical.... } \\
\ldots \ldots \text {.do...... } \\
\text {....do..... }\end{array}$} & \multirow[t]{2}{*}{$\begin{array}{l}\text { Light.... } \\
\text { Medium } \\
\text { Daris.... }\end{array}$} & $\begin{array}{l}64.0 \\
64.0 \\
64.0\end{array}$ & $\begin{array}{r}12.1 \\
9.6 \\
13.8\end{array}$ & $\begin{array}{l}1,405 \\
2,220 \\
1,405\end{array}$ & & $\begin{array}{l}2,250 \\
1,750 \\
1,500\end{array}$ & $\begin{array}{l}2,000,000 \\
2,800,000 \\
2,200,000\end{array}$ \\
\hline & Average. & & & 64.0 & 11.8 & 1,680 & 3,770 & 1,830 & $2,330,000$ \\
\hline \multirow[t]{2}{*}{$\begin{array}{l}\mathrm{B} \\
\mathrm{B} \ldots \ldots . \\
\mathrm{B} \ldots \ldots .\end{array}$} & 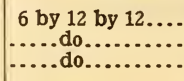 & \multirow[t]{2}{*}{$\begin{array}{l}\text { Vertical.... } \\
\text { …do...... } \\
\text { ….do..... }\end{array}$} & \multirow[t]{2}{*}{$\begin{array}{l}\text { Light.... } \\
\text { Medium } \\
\text { Dark.... }\end{array}$} & $\begin{array}{l}38.0 \\
38.0 \\
38.0\end{array}$ & $\begin{array}{l}22.9 \\
13.1 \\
13.6\end{array}$ & $\begin{array}{l}1,320 \\
1,695 \\
2,700\end{array}$ & & $\begin{array}{l}2,160 \\
1,870 \\
2,250\end{array}$ & $\begin{array}{l}3,700,000 \\
4,400,000\end{array}$ \\
\hline & Average.. & & & 38.0 & 16.5 & 1,905 & 3,610 & 2,090 & $4,050,000$ \\
\hline & \begin{tabular}{l}
12 by 12 by $12 \ldots$ \\
\hdashline$\ldots d o$
\end{tabular} & \begin{tabular}{c} 
Horizontal. \\
\hdashline$\ldots$ do $\ldots . . .$. \\
$\ldots$. do
\end{tabular} & $\begin{array}{l}\text { Light.... } \\
\text { Medium } \\
\text { Dark.... }\end{array}$ & $\begin{array}{l}34.0 \\
34.0 \\
34.0\end{array}$ & $\begin{array}{r}13.9 \\
9.6 \\
7.5\end{array}$ & $\begin{array}{l}490 \\
460 \\
520\end{array}$ & $\begin{array}{l}2,070 \\
1,950 \\
2,210\end{array}$ & $\begin{array}{r}750 \\
1,000\end{array}$ & $\begin{array}{l}2,500,000 \\
3,300,000 \\
4,700,000\end{array}$ \\
\hline & Average.. & & & 34.0 & 10.3 & 490 & 2,080 & 875 & $3,500,000$ \\
\hline $\begin{array}{l}\text { B... } \\
\text { B... } \\
\text { B... }\end{array}$ & $\begin{array}{c}6 \text { by } 12 \text { by } 12 \ldots \\
\cdots \\
\cdots\end{array}$ & $\begin{array}{c}\text { Horizontal. } \\
\text {.....do....... } \\
\text {.....do..... }\end{array}$ & $\begin{array}{l}\text { Light.... } \\
\text { Medium } \\
\text { Dark.... }\end{array}$ & $\begin{array}{l}22.5 \\
22.5 \\
22.5\end{array}$ & $\begin{array}{l}17.4 \\
16.3 \\
17.6\end{array}$ & $\begin{array}{l}480 \\
610 \\
670\end{array}$ & & $\begin{array}{l}1,110 \\
1,510 \\
1,110\end{array}$ & $\begin{array}{l}1,100,000 \\
1,600,000 \\
1,900,000\end{array}$ \\
\hline & & & & 22.5 & 17.1 & 585 & 1,870 & 1,240 & $1,530,000$ \\
\hline
\end{tabular}




\section{TESTS OF THE WALLS.}

The walls fall into groups, depending on the construction or the method of loading. All the walls were axially loaded except those in Series III, for which the load had an eccentricity of 2 inches. A sectional view of wall No. I9 under eccentric load is given in Figure 3 .

Compressometer readings were taken at each corner of the wall, with the gauge length nearly the height of the wall. Readings were taken with a Berry strain gauge on several 8-inch gauge lines, some on individual tile, and some across horizontal joints. The method of measuring these deformations wasessentially that described in Technologic Papers Nos. I I I and I 20.

The horizontal deflection at mid height of the wall was measured with a scale from a wire hung vertically near the center line of one side of the wall. The effect of loading the walls was carefully noted. Any cracking or spalling was recorded.

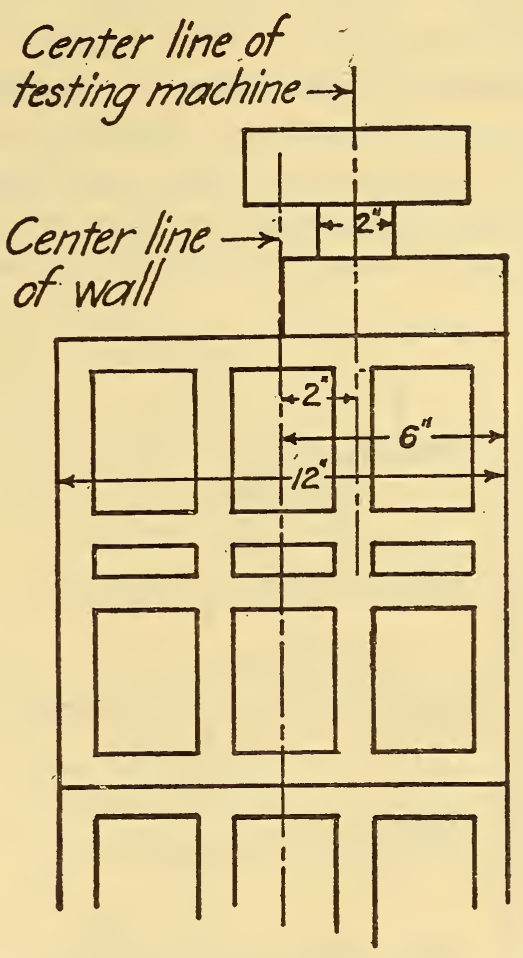

FIG. 3.-Cross-sectional view of wall with cells horizontal, showing method of applying the eccentric load.

\section{RESULTS, WITH DISCUSSION OF THE TESTS.}

\section{TESTS OF MORTAR.}

The tensile strength of the mortar after being stored in air for six months was $275 \mathrm{lbs}$./in. ${ }^{2}$ The specimens stored in water for six months averaged $358 \mathrm{lbs}$. $/$ in. ${ }^{2}$

The compressive specimens were 2 -inch cubes. Stored in air, their strength averaged I,750 lbs./in. ${ }^{2}$ after seven days, and 2,700 1bs./in. ${ }^{2}$ after six months. Those stored in water for six months averaged $4,000 \mathrm{lbs}$./in. ${ }^{2}$

\section{TESTS OF INDIVIDUAL TILE.}

The results of the tests on individual tile are given in Table $\mathrm{I}$. They indicate that the tile used for these walls had approximately the same properties as those reported in Technologic Paper No 120. 


\section{TESTS OF THE WALLS.}

The results of the wall tests are found in Table 2 and in Figure 4. The thickness of the wall is the first figure under "Size of wall tile." Under the heading "Ultimate strength" are given four sets of values for the strength of the walls. The first of these columns gives the maximum load on the wall in pounds. The next, the load in short tons $(2,000$ pounds) sustained by each linear foot of the wall. The actual lengths varied from $48 \mathrm{I} / 2$ to $5 \mathrm{I}$ inches. In the third column will be found the stress for the gross area and. in the fourth the stress for the net sectional area of the wall.

The strength at first crack

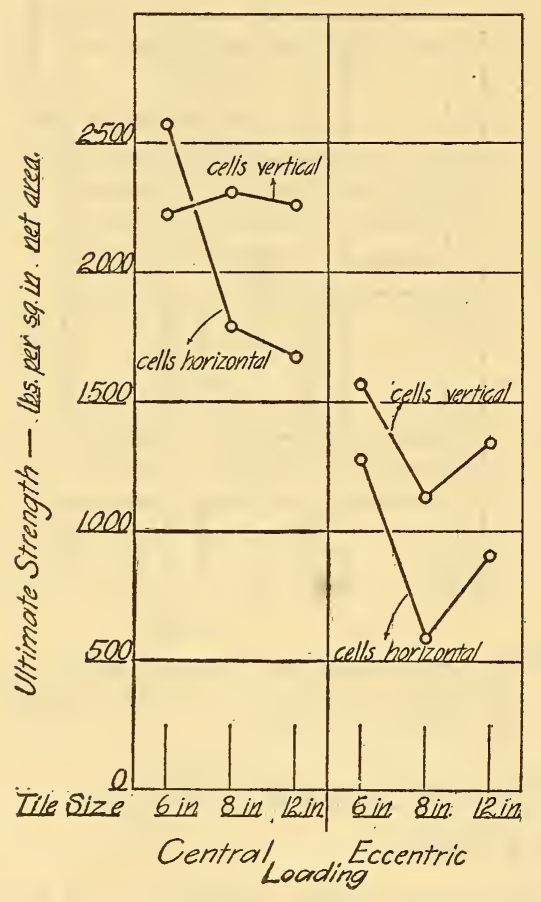

Fig. 4.-Ultimate strengths for the walls built of Ohio tiles. was the load at which the first indication of failure occurred, either cracking or spalling. A discussion of the behavior of these walls under load may be given as follows:

(a) Although the strength of the individual tile in lot $\mathrm{A}$ was about twice that for the tile in lot $B$, the strengths of the walls made from these tile were only slightly greater. The ultimate strength of the walls made from the $\mathrm{A}$ tile averaged about 37 per cent of the strength of the individual tile, while those made from the B tile averaged about 55 per cent.

(b) From the theory of columns it might be expected that a thick wall, the height being the same, would sustain a greater load than a thin one. These tests, on the contrary, show no effects which can be definitely ascribed to "column action," although the slenderness ratio for the 6-inch walls was over 60 . This is confirmed by the small deflection of the walls.

(c) Apparently there is no relation between the ultimate strength of a wall and the load at first crack.

(d) The walls having the cells of the tile vertical had, on the average, more than twice the strength of those having the cells horizontal. For both these cases the values of the stress at 
failure were remarkably constant for the tile in lot A on end, being apparently independent of the size of the tile. The ultimate stresses, computed on the net sectional area, were also somewhat greater for the walls having the cells vertical, except for the 6-inch A tile, for which the stresses in the walls having the cells horizontal were slightly greater. Apparently the advantage of setting the tile with the cells vertical is greater for eccentrically loaded walls than for walls which are axially loaded.

(e) In only one case could a direct comparison be made between "broken" and "unbroken" joints. Wall No. 3I with "broken" joints, but in all other respects identical in construction with walls Nos. 25 and 26, which had "unbroken" joints, shows a much higher strength. Conclusions, however, should not be drawn from the results from one specimen. Attention is called to the fact that in these tile the transverse webs were spaced to give full bearing over the end of the tile when the cells were vertical and the joints "broken," as well as when the joints were "unbroken."

(f) For the axially loaded walls the failure was sometimes by crushing at the top and sometimes by vertical cracking through the joints. No consistent difference in strength was found for these two types of failure. Probably the crushing at the top was determined by the plaster cap, which was somewhat weaker than the mortar joint.

(g) Walls loaded with an eccentricity of 2 inches over onehalf the width of the wall had about one-half the strength of similar walls axially loaded. Apparently this ratio is independent of the thickness of the wall. The maximum deflection for the eccentrically loaded walls was, on the average, 0.04 inch, undoubtedly a very small value, which was exceeded by six of the axially loaded walls.

(h) Failure in the case of the eccentrically loaded walls was local. The upper bearing plate (fig. 3) rested on two of the webs of each tile in the upper course. The stress in these webs was, therefore, much greater than in the lower courses in which the load was more uniformly distributed.

(i) As it was found that the modulus of elasticity varied greatly for tile in the same wall and because the value for the tile upon which gauge lines were placed was unknown, the strain-gauge readings were of little use. The readings on the same gauge line did not vary with the load, but were often very erratic. 
This may have been due to a redistribution of the stress as the load increased. In general, the deformation across a joint was much greater than for the adjacent tile, in many cases being twice as great.

(j) The deformation of the wall, as a whole, is shown in Figure 5, for wall No. I, under axial loading. These compressometer

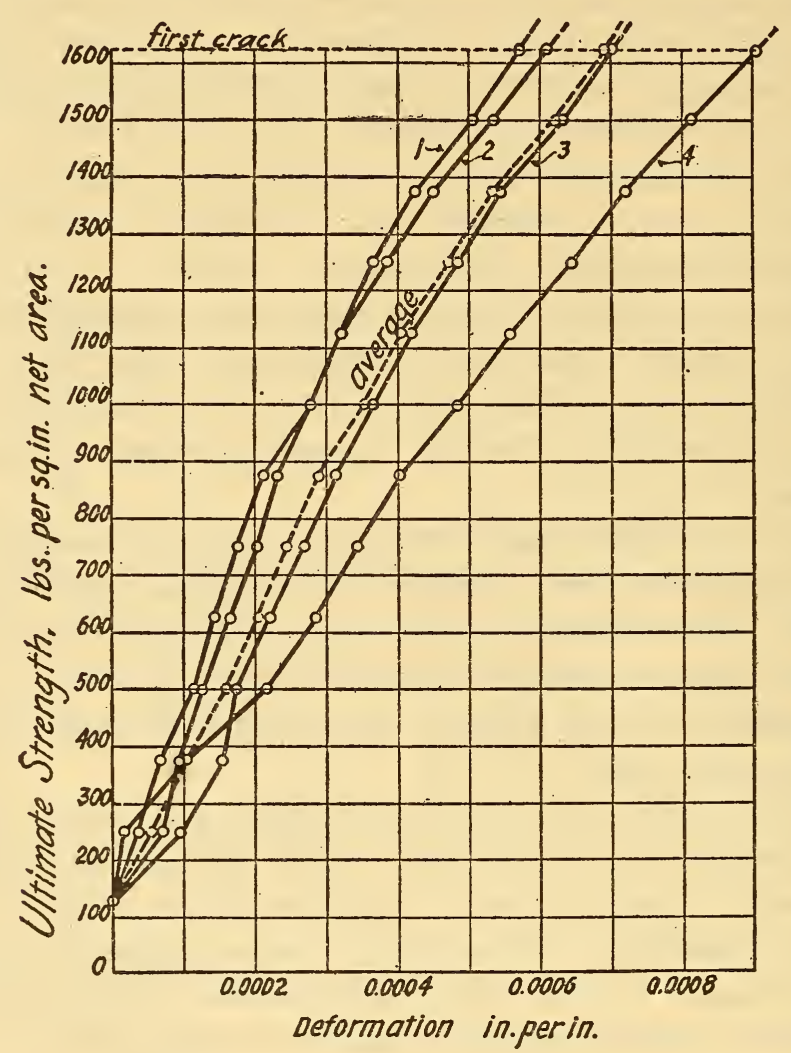

FIG. 5.-Characteristic compressometer curves, showing deformation of wall No. I under central loading. I. NE. corner; 2. SW.; 3. NW.; 4. SE.

curves are characteristic for the axially loaded walls. Similar curves, which are characteristic of the eccentrically loaded walls, are shown in Figure 6 for wall No. I9.

(k) The modulus of elasticity of the walls varied over a wide range, and apparently there is no relation between the modulus for the wall and that for the individual tile. 


\section{GENERAL SUMMARY.}

I. The walls built of high-strength tile were set with great care by an experienced mason. They were, undoubtedly, much stronger than walls built under ordinary commercial conditions.

2. Great differences in the strength of the tile do not appear to have an appreciable effect on the strength of the walls.

3. The stress at failure of the thin walls was about the same as for the thick walls, showing that there was no appreciable "column action."

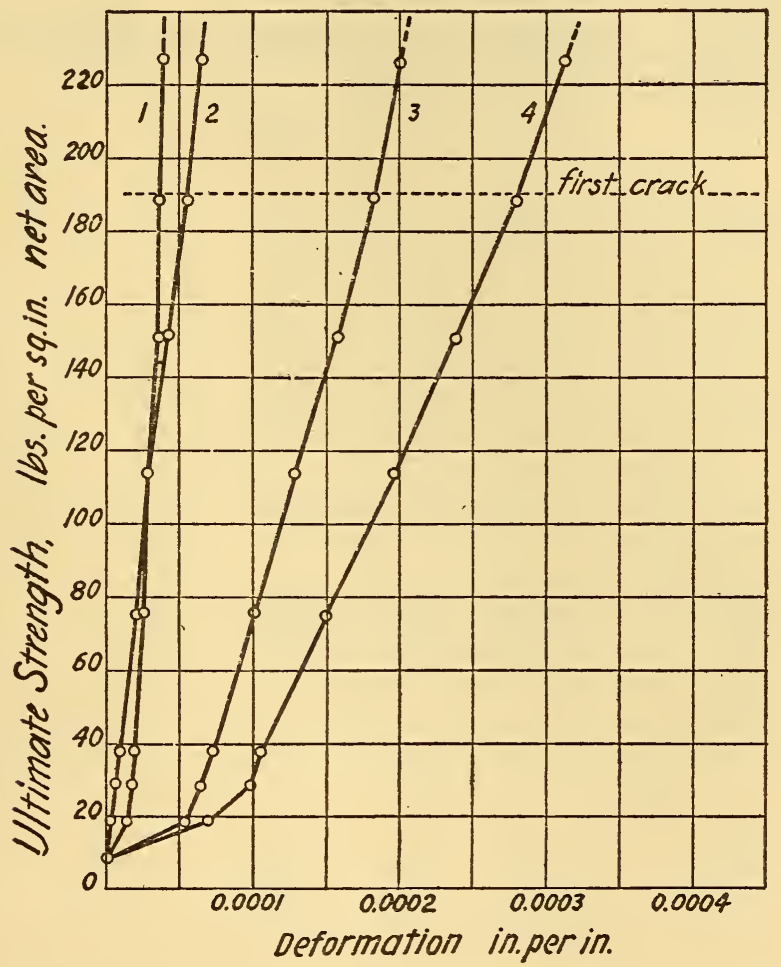

FIG. 6.-Characteristic compressometer curves, showing deformation of wall No. I9 under eccentric loading. I. NE. corner; 2. SE.; 3. NW.; 4. SW.

Load applied on a north-south line, 2 inches west of longitudinal center plane of wall.

4. No relation was found between the ultimate strength and the load at first crack.

5. The stress at failure, computed on the net sectional area, was remarkably constant for the tile in lot $\mathrm{A}$ on end being, independent of the size of the tile.

6. The walls having the cells of the tile vertical had, on the average, more than twice the strength of those having the cells horizontal. 
7. Walls loaded with an eccentricity of 2 inches over one-half the width of the wall had about one-half the strength of similar walls axially loaded. Apparently this ratio is independent of the thickness of the wall.

8. The eccentrically loaded walls failed by crushing of the tile under the bearing plate.

9. Due to the wide differences in the modulus of elasticity of the tile strain-gauge readings were of little use. In general, the deformation across a joint was much greater than for the adjacent tile, in many cases being twice as great.

Io. No relation could be found between the modulus of elasticity for the wall and that for the tile. 


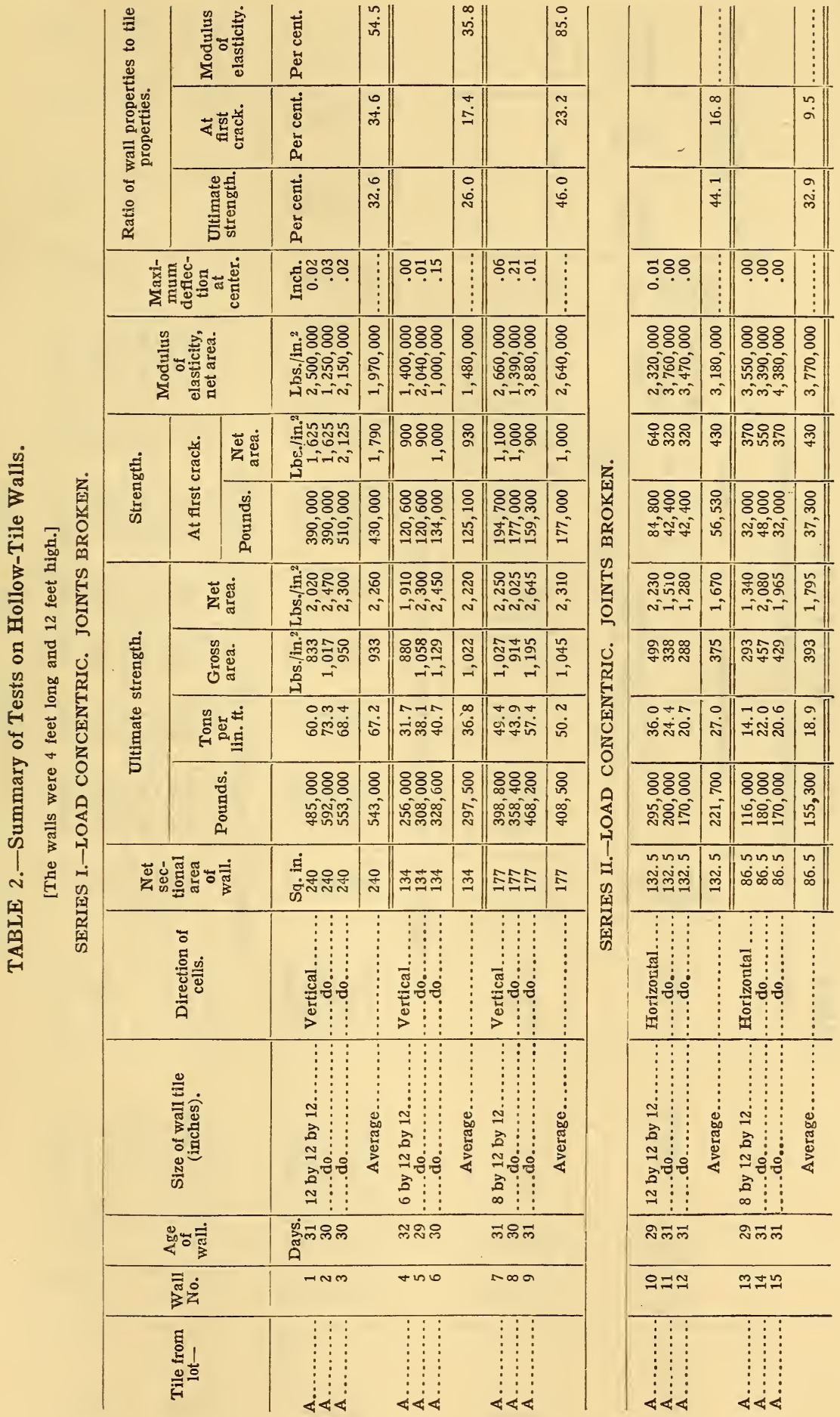



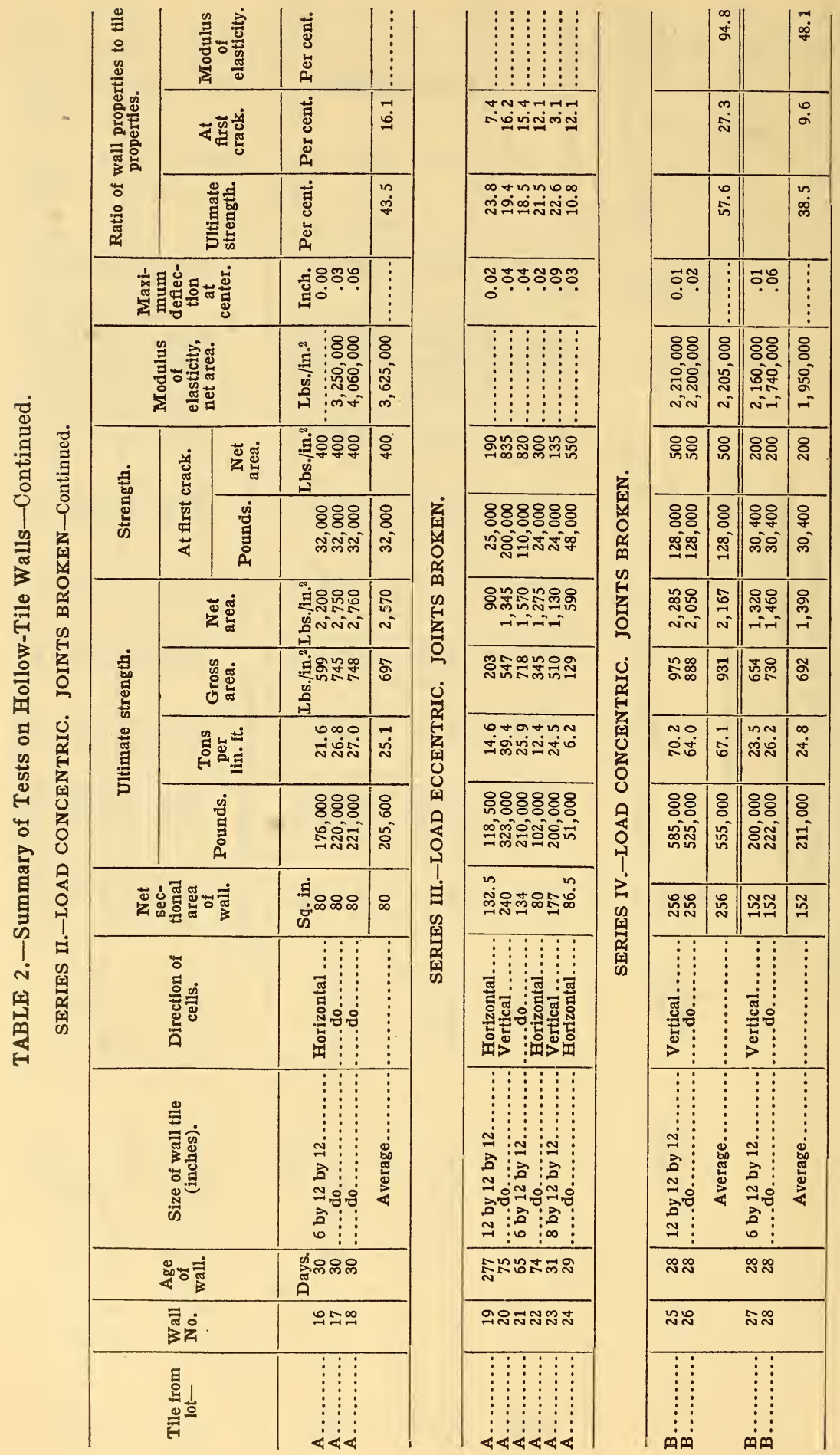


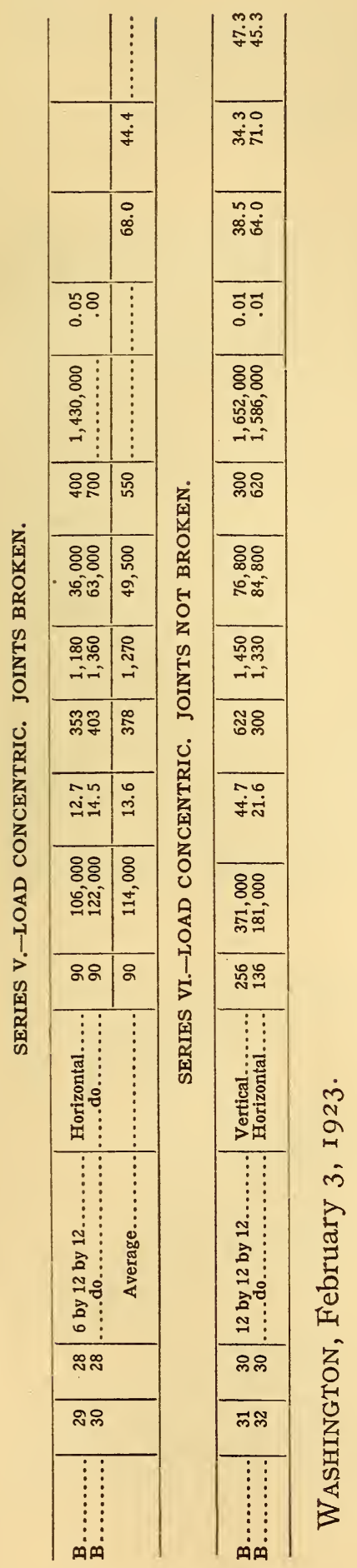

